\title{
Why buildings collapse in the earthquakes, Turkey case
}

\author{
Ali Serdar ECEMiŞ \\ Necmettin Erbakan University, Civil Engineering Department, Konya-Turkey
}

\begin{abstract}
Many European countries with shores to the Mediterranean are under earthquake risk. Earthquakes in Turkey in the last 50 years caused lost of more than 50,000 human lives. Reinforced concrete buildings can collapse and cause loss of life even in earthquakes smaller than the design earthquakes defined by the seismic code. In this study, housing construction system and earthquake-resistant buildings in terms of system production problems in Turkey were discussed. The most common damage types after earthquakes are summarized.
\end{abstract}

Keywords: Earthquake, reinforced concrete, housing, failure, fault.

\section{Introduction}

Italy, Greece and Turkey are the countries in the Mediterranean coast and the active earthquake zone. Earthquakes in this region have caused many destructions throughout history and today. Especially in the last 30 years as a result of the reinforced concrete buildings collapsed in earthquakes in Turkey it has been the loss of many lives. Earthquakes and casualties that occurred in Turkey in the last 25 years are summarized in Table 1. When the earthquake damage characters in reinforced concrete buildings are examined, it is seen that similar design and construction errors were observed. Faults that cause failure were repeated during the design and construction stages. In the country that suffered heavy losses in every earthquake, the same mistakes are repeated in the construction of new buildings.

Table 1 Earthquakes and casualties in Turkey in the last 25 years

\begin{tabular}{|c|c|c|c|c|c|c|c|}
\hline Date & Location & Dead & Magnitude & Date & Location & Dead & Magnitude \\
\hline 23.Feb.20 & $\begin{array}{l}\text { Iran-Turkey } \\
\text { Border }\end{array}$ & 10 & $6.0 \mathrm{M}_{\mathrm{w}}$ & 01.May.03 & $\underline{\text { Bingöl }}$ & 177 & $6.4 \mathrm{M}_{\mathrm{w}}$ \\
\hline 24.Jan.20 & Elazığ & 44 & $6.8 \mathrm{M}_{\mathrm{w}}$ & 27.Jan.03 & Tunceli & 1 & $6.1 \mathrm{M}_{\mathrm{w}}$ \\
\hline 09.Nov.11 & Edremit, Van & 40 & $5.6 \mathrm{M}_{\mathrm{w}}$ & 3.Feb.02 & $\underline{\text { Sultandağ } 1,}$ & 44 & $6.5 \mathrm{M}_{\mathrm{w}}$ \\
\hline 23.Oct.11 & Tabanl1, Van & 601 & $7.2 \mathrm{M}_{\mathrm{w}}$ & & Afyonkarahisar & & $5.8 \mathrm{M}_{\mathrm{w}}$ \\
\hline 19.May.11 & Kütahya & 2 & $5.8 \mathrm{M}_{\mathrm{w}}$ & 15.Nov.00 & Afyonkarahisar & 6 & $5.8 \mathrm{M}_{\mathrm{w}}$ \\
\hline 8.Mar.10 & Elazığ & 41 & $6.1 \mathrm{M}_{\mathrm{w}}$ & 6.Jun.00 & Çankırı & 3 & $6.1 \mathrm{M}_{\mathrm{w}}$ \\
\hline 17.Oct.05 & $\underline{\underline{\text { Izmir }}}$ & 2 & $5.7 \mathrm{M}_{\mathrm{w}}$ & 12.Nov.99 & Düzce & 894 & $7.2 \mathrm{M}_{\mathrm{w}}$ \\
\hline 21.Oct.05 & & & $5.9 \mathrm{M}_{\mathrm{w}}$ & 17.Ağu.99 & Gölcük, Kocaeli & 17.118 & $7.4 \mathrm{M}_{\mathrm{w}}$ \\
\hline 25.Jan.05 & Hakkâri & 2 & $4.8 \mathrm{M}_{\mathrm{w}}$ & 27.Jun.98 & Ceyhan, Adana & 146 & $6.2 \mathrm{M}_{\mathrm{S}}$ \\
\hline 02.July.04 & $\overline{\text { Ağr1 }}$ & 18 & $5.2 \mathrm{M}_{\mathrm{w}}$ & 1.Oct.95 & Afyonkarahisar & 90 & $6.1 \mathrm{M}_{\mathrm{S}}$ \\
\hline 28.Mar.04 & Erzurum & 9 & $5.3 \mathrm{M}_{\mathrm{w}}$ & 13.Mar.92 & Erzincan & 653 & $6.8 \mathrm{M}_{\mathrm{S}}$ \\
\hline
\end{tabular}

In this study, general structural properties of buildings (residential) in Turkey were summarized and observed earthquake damage types were classified. Design and construction defects that caused the observed damages have been explained. The cause of the damage has been explained by comparing the rules defined in the earthquake regulation and the details actually applied.

\section{Causes of poor quality housing stock formation}

After World War 2, Turkey, was subjected to a rapid population growth and migration from rural to urban. The total population in Turkey is given in Figure 1. The rapid increase in the city population has resulted in 
uncontrolled housing construction process. During the construction process, the state's inadequate and ineffective control mechanism continued until 2010.

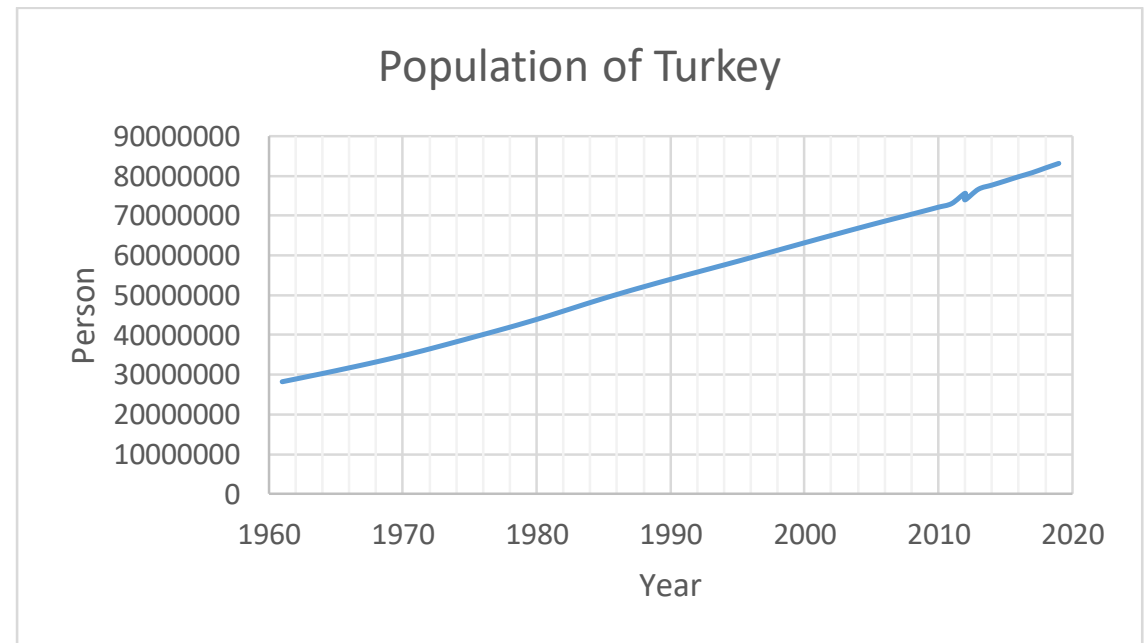

Figure 1 Population growth of Turkey

Despite the population increase in the country, the fact that the national income did not increase at the same rate, made it difficult for the majority of the people to obtain housing. Under this economic constraint, "cooperative system type" building had become popular in housing construction. With the limited dues collected from the members, there were housing constructions that last for years. Generally, the cooperative management was carried out by non-civil engineers or architects.

A second type of house production was "construction through builders-contractors". Again, builders who were not architects or engineers, who only had capital, obtained land-parcel and sold it after building a house. In this case, housing quality was problematic as maximum profit was aimed [1-3].

During the design phase of most of the residential buildings, architectural projects were prepared, and the static or reinforced concrete project was obtained with low project costs. Although there was a scientifically qualified earthquake regulation in the country and it is updated, many projects had emerged that did not comply with the earthquake regulation during the design phase. Project approval process was carried out in municipalities. The approval process in the municipality contained technical deficiencies. Therefore, projects with design flaws could also be approved. The quality of the design projects made in the engineering offices was also problematic since the engineers could not get the sufficient project costs during the design process.

At this point, the society had not been able to understand the importance of the static project and perceives the project only as a document required to obtain approval from the municipality. It was not understood by the public that the mistake made during the design caused the destruction of the building during the earthquake. There was a perception that the fee paid for the project is unnecessary. In addition, there was no fixed application regarding project fees in the country. Project costs were very low due to the competition between the large number of project offices. Project offices carried out many projects over their capacity at low prices [4-6].

During the construction process, engineers were completely disabled. Although it was legally required to have an engineer on the construction site, generally there were no engineers on any site. In housing construction, workers were directly managed by the head of the cooperative or contractor. The decisions to be taken by the employer, who was not a civil engineer, caused deficient structures to emerge.

Except for engineering profession, people in charge of construction or construction were not informed about concrete casting, application of reinforcement details, etc. The most important problem was that the employer, who could not technically understand the importance of the manufacturing details, took responsibility on the construction site. As an example of the problems that may arise, the concrete casting stage can be given. Workers prefer to add more water than hydration in order for the concrete to settle 
easily. As a result of the lack of a responsible civil engineer at the construction site, the concrete used mostly has a high water / cement ratio. In addition, details such as 135 degree bending of stirrup hooks, formation of stirrup confinement zone, applying the necessary cover concrete margins can only be applied on site by engineers who has the reinforced concrete knowledge. Workers who produced the reinforcements, made stirrup hooks at 90 degrees due to the ease of construction and preferred not to comply with the stirrup spacing [7].

The state's control mechanism in housing construction was quite ineffective. The engineer in charge of the construction control was assigned by the employer, and the wage payment was made by the employer. The engineer in charge of controlling the person from whom he received money was often unable to recover his fee. The project fee included the control engineering fee. The project engineer was generally the control engineer also and often didn't go to the site. Therefore, on-site manufacturing was carried out only with the experience of construction workers.

The biggest problem in housing construction was poor quality concrete production. In parallel with the technological level of the country, ready-mixed concrete production had become widespread after 1995. Concrete production was done by workers at construction sites. In some cases, concrete was mixed with shovels without using a machine. It was impossible to comply with the design mixture, water / cement ratio in production. A high amount of water was used for easy concrete casting. According to the experience of the author, strengths of $7 \mathrm{Mpa}$ or less were found in core results taken from old buildings. Buildings can collapse under their own weight without an earthquake as a result of its low concrete strength. 1983 Diyarbakır Hicret Apartment 34 Dead), 2004 Konya Zümrüt Site (92 Dead) can be given as examples (Figure 2).

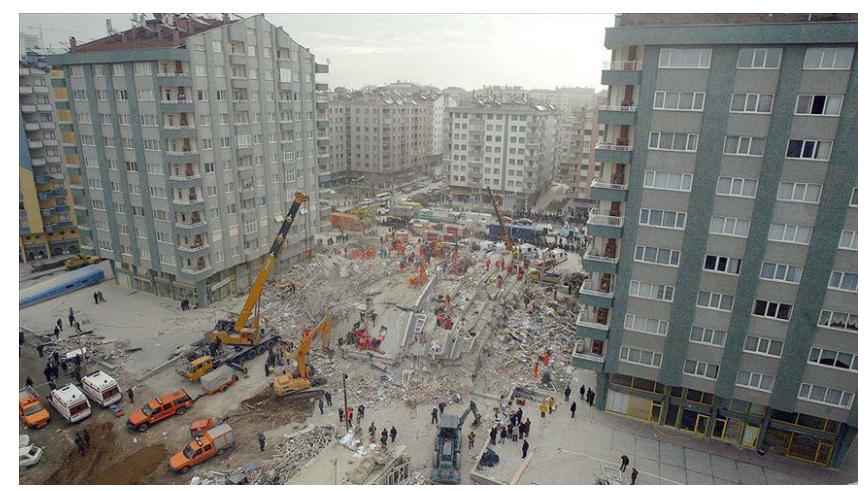

Figure 2 Failure of Zumrut Apartment [8]

\section{Types of damage observed in reinforced concrete houses after the earthquakes}

Most of the residential buildings are reinforced concrete structures. Steel or prefabricated structures are made for industrial facilities. Reinforced concrete residential buildings are mostly between 3-10 floors. In terms of the building structural load carrying system, framed structures consisting of columns and beams are common. Shear walls are not sufficient in old buildings. Insufficient lateral rigidity caused excessive damage and collapse in buildings (Figure 3). Due to the lack of lateral rigidity, significant damage occurred in the brick walls (Figure 4). In this case, it made the building difficult to use after an earthquake and significantly increased the need for temporary post earthquake housing. 


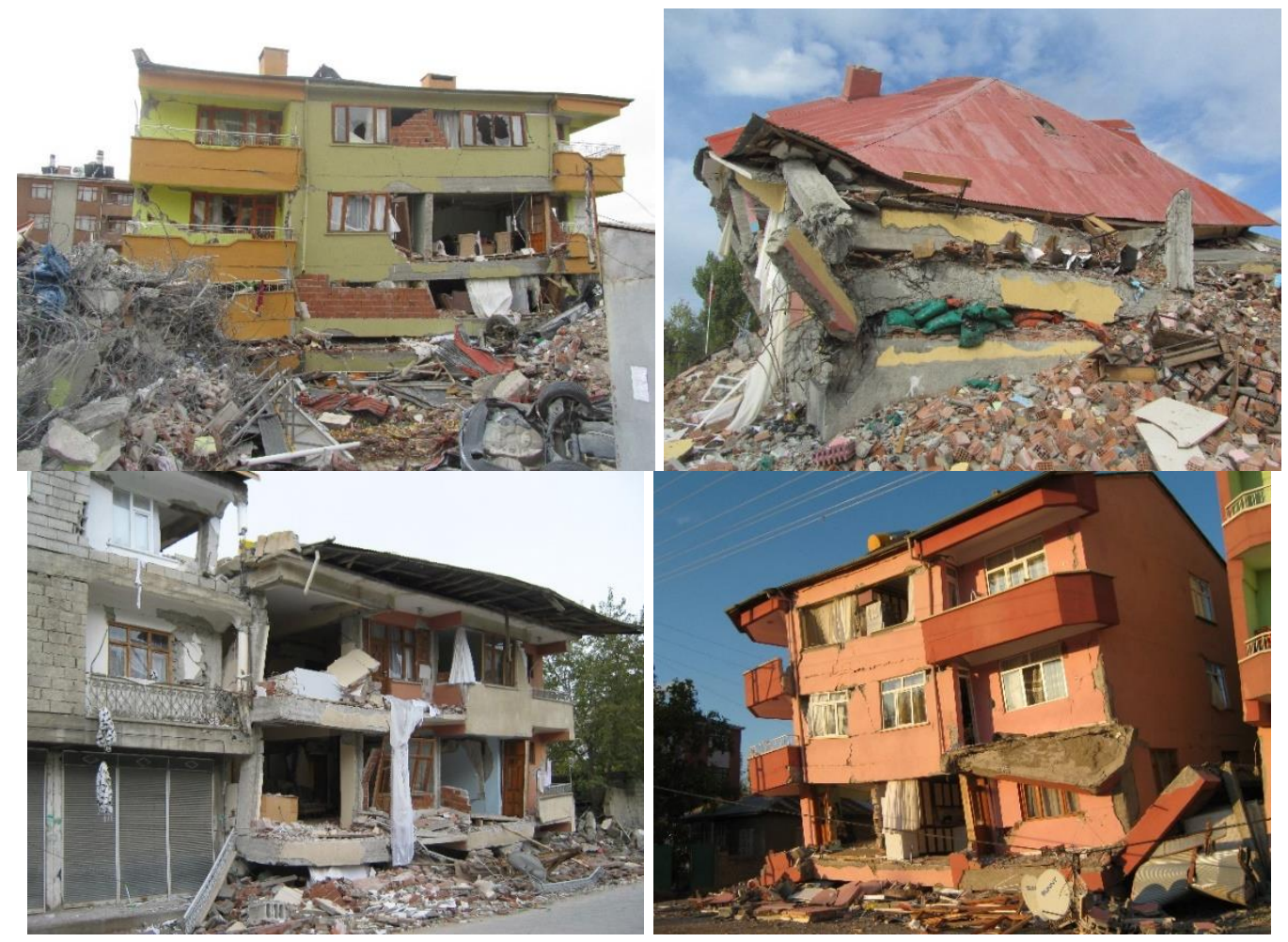

Figure 3 Failure of RC building due to insufficient lateral rigidity

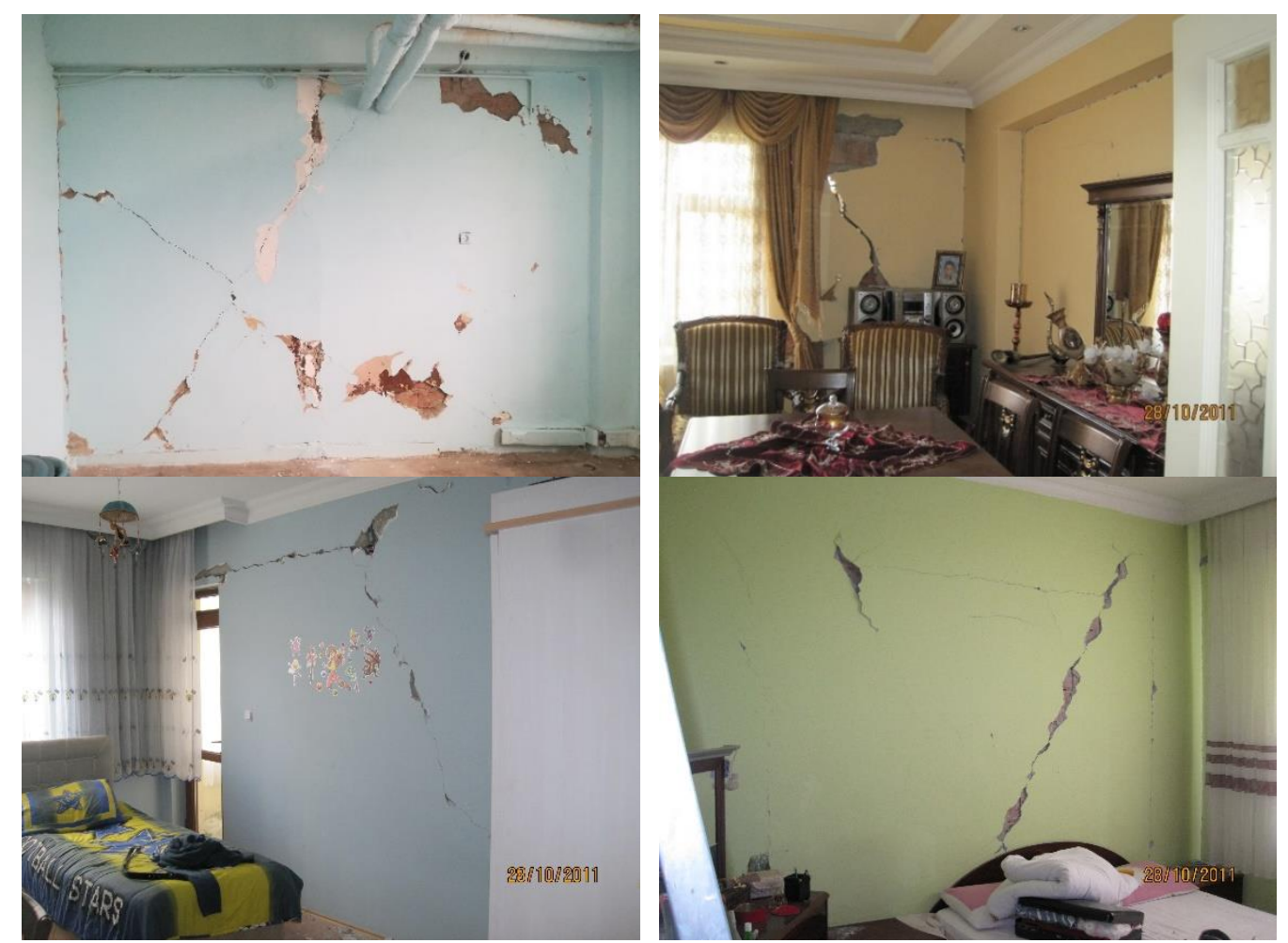

Figure 4 Excessive damage in brick infill walls

In framed structures, it is important to distribute the column stiffness equally in both vertical directions. When the column had strong axes in only one direction, significant damage occured in the structure when the earthquake came from the other vertical direction (Figure 5). 


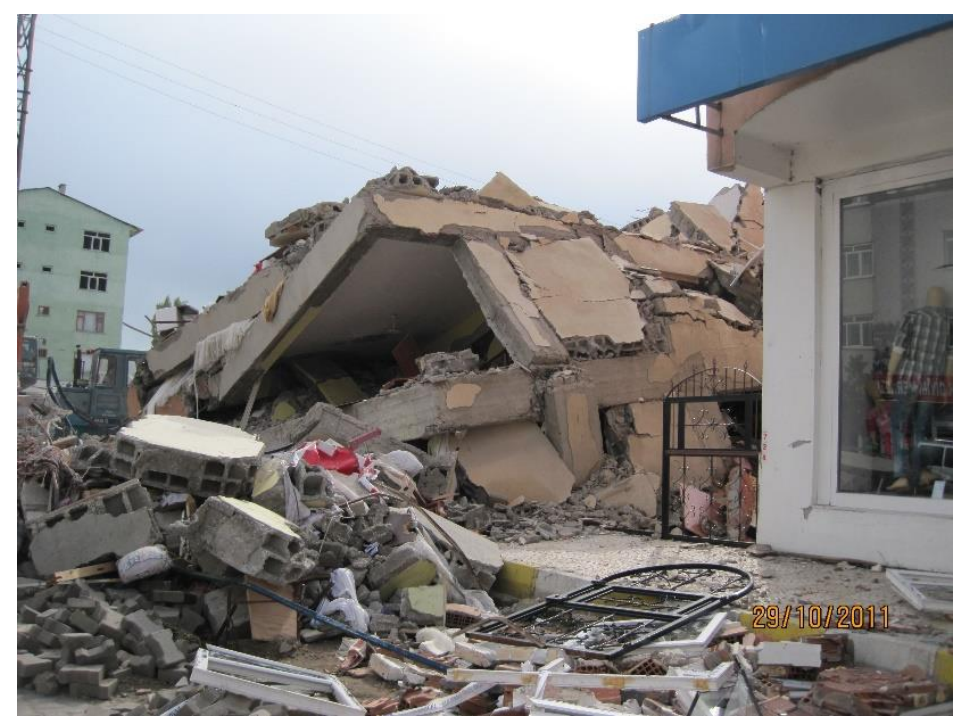

Figure 5 Failure due to column orientation

Structure geometry has a significant effect on earthquake resistance. It is difficult to provide earthquake resistance of non-symmetrical structures (Figure 6). Behavior of unsymmetrical structures under dynamic loads is very complex and to predict response of the structure require higher engineering knowledge and analysis skills.
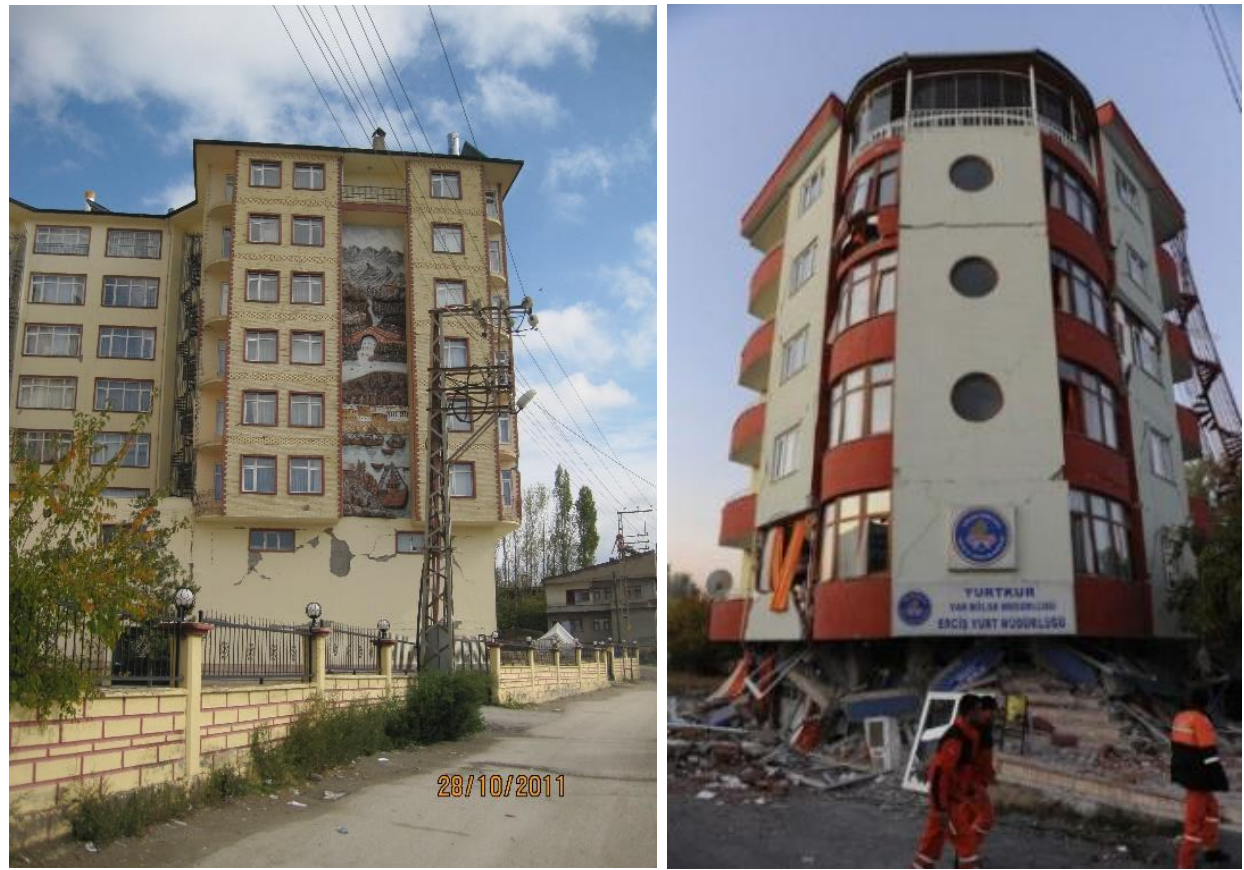

Figure 6 Damage to unsymmetrical irregular structure

The stirrup confinement zones in columns and beams in framed structures were not complied with. Stirrup intervals were far above the ranges given in the seismic regulation (Figure 7). In addition, stirrup hooks bent 90 degrees instead of 135 degrees (Figure 8). In addition, concrete cover was not complied with in reinforced concrete elements. Insufficient cover and stirrups with 90 degree hooks were easily opened during an earthquake. 


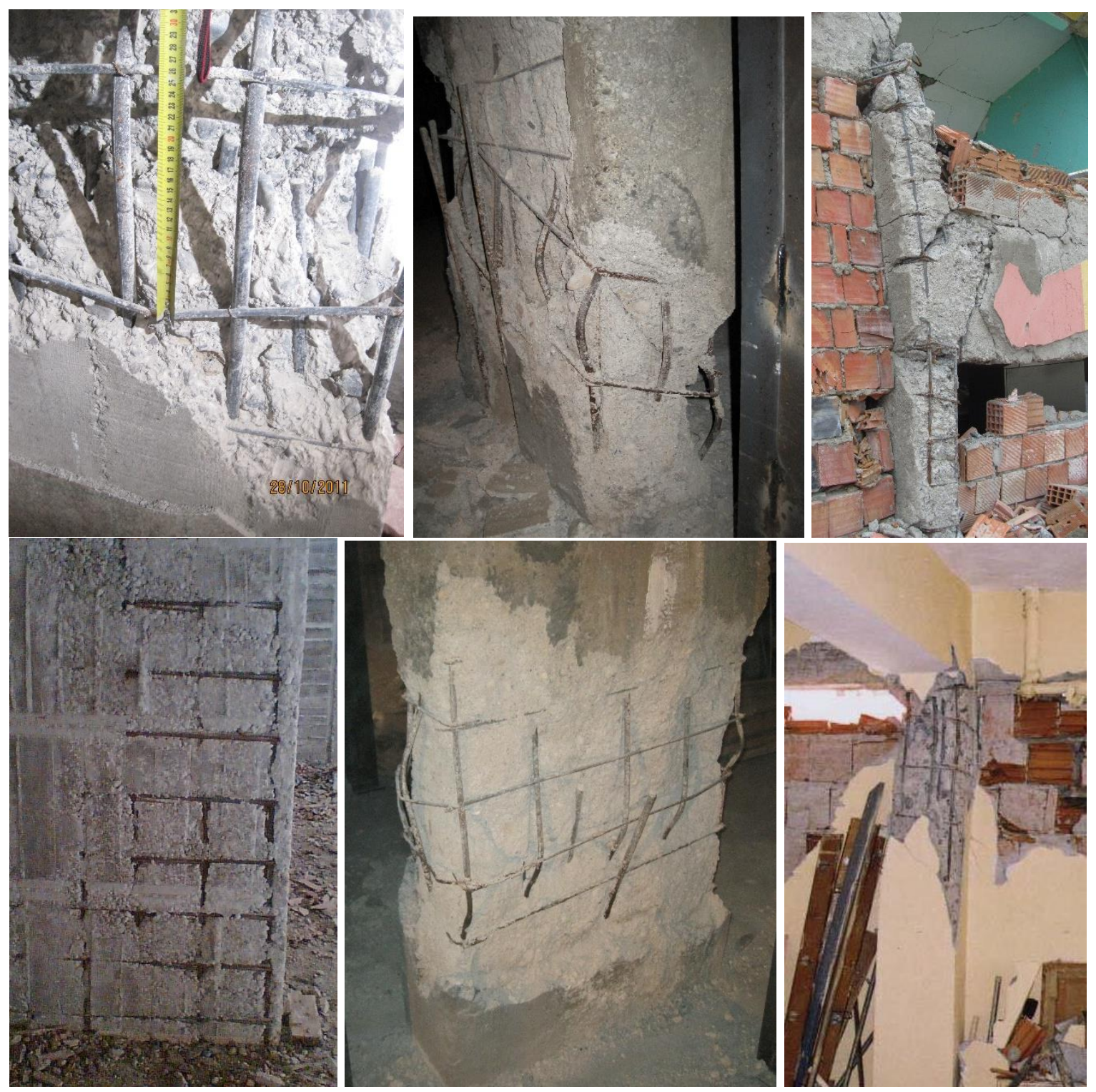

Figure 7 Stirrup intervals in columns

With the failure of the stirrups, the confined concrete behavior disappears. Unconfined column behavior is far from ductile properties. The deficiencies in stirrup workmanship damaged the columns in terms of both strength and ductility. It was observed that the longitudinal reinforcements buckled after the stirrup lost its effect (Figure 8).
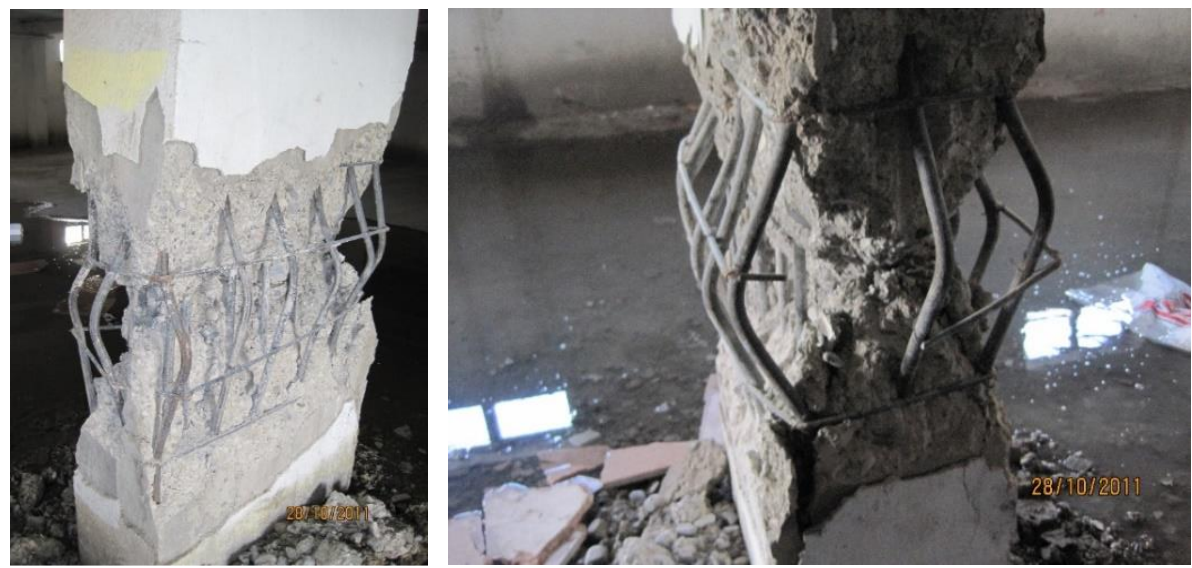

Figure 8 Buckling of longitudinal reinforcements

Stirrup confinement zones were often not encountered in the columns. Strong beam-weak column formation was common in column beam joints. Hinges occurred in the columns under horizontal loads. In addition, 
there were no stirrups in column beam connections. Joints were far from being able to accommodate shear forces (Figure 9).

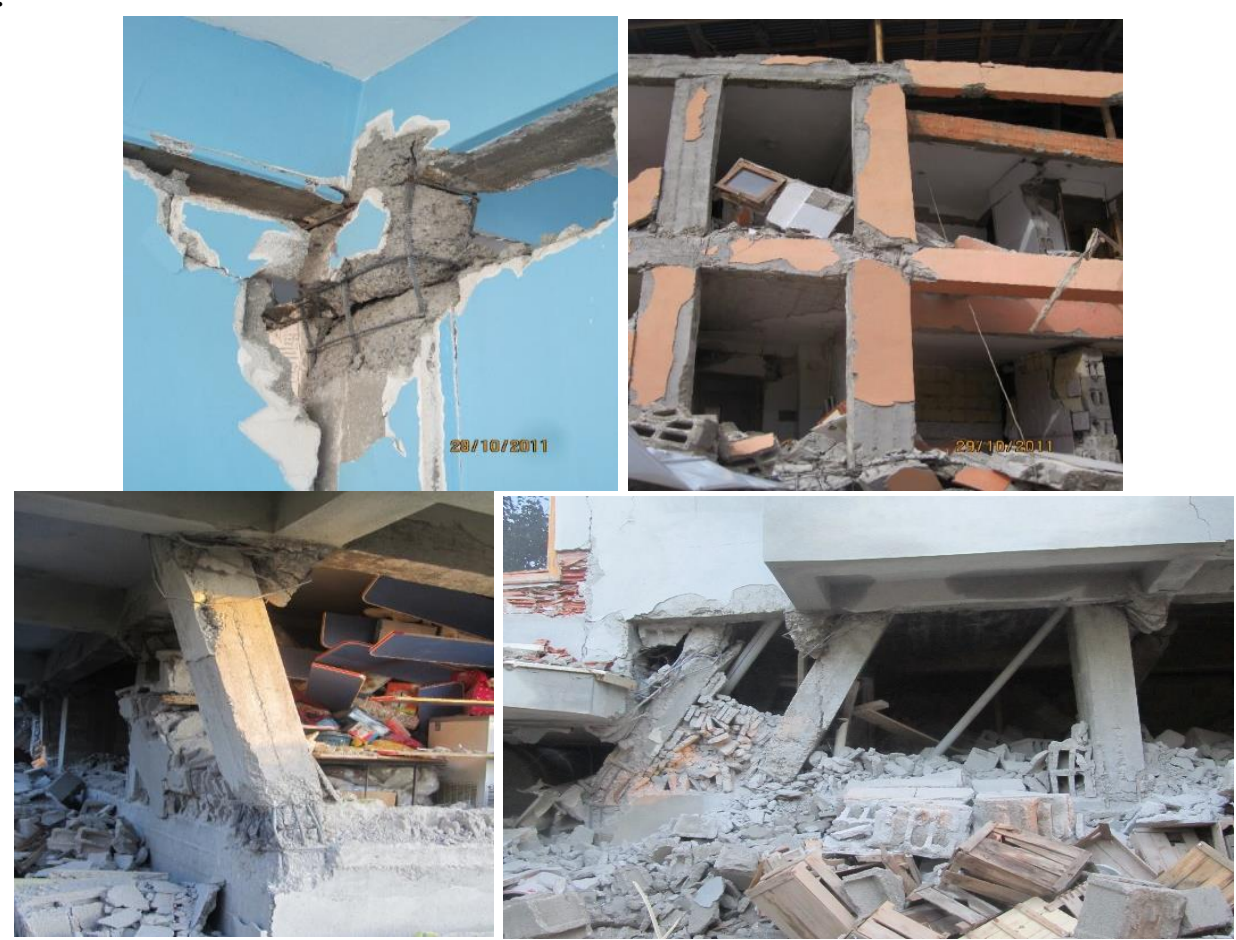

Figure 9 Failure of beam-column joints

The ground floors of the buildings were generally used as shops. Brick walls on the upper floors contributed to frame rigidity. The absence of these walls on the lower floors caused irregularities in strength between the floors. Soft floor type failure was the most common type of failure under earthquake loads (Figure 10). In these structures, under horizontal loads, the joints were formed only in the lower floor columns and the system collapsed before reaching the sufficient ductility and energy consumption capacity.

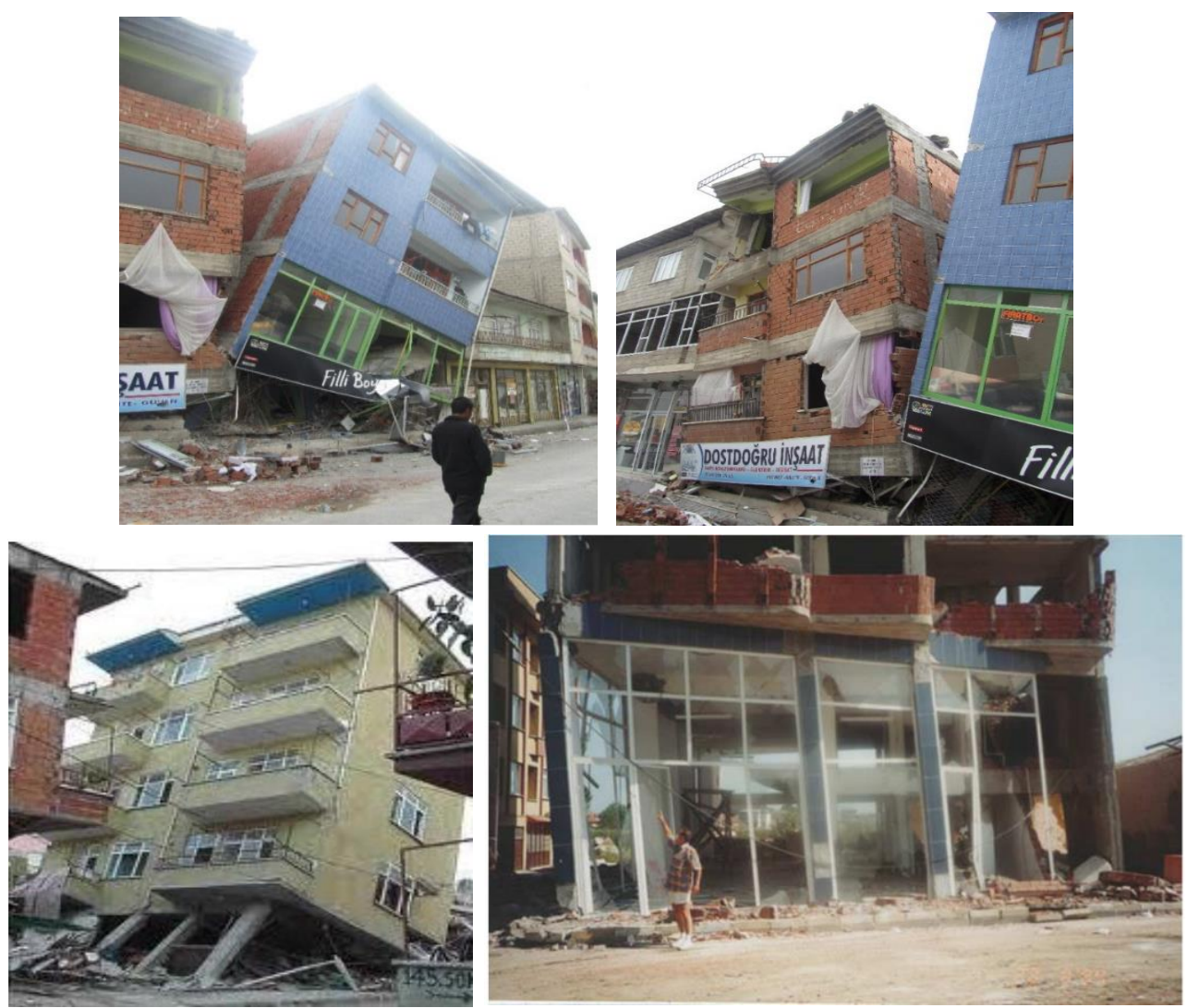

Figure 10 Soft story failures [9-10] 
Short column formation occurred by partially building the brick walls in the frame and leaving a bandshaped window on it. Columns with a shorter length than the one considered in the design had more shear forces than the strength and the column was exposed to brittle shear fracture (Figure 11). This failure significantly decreased the ductility and strength of the building.

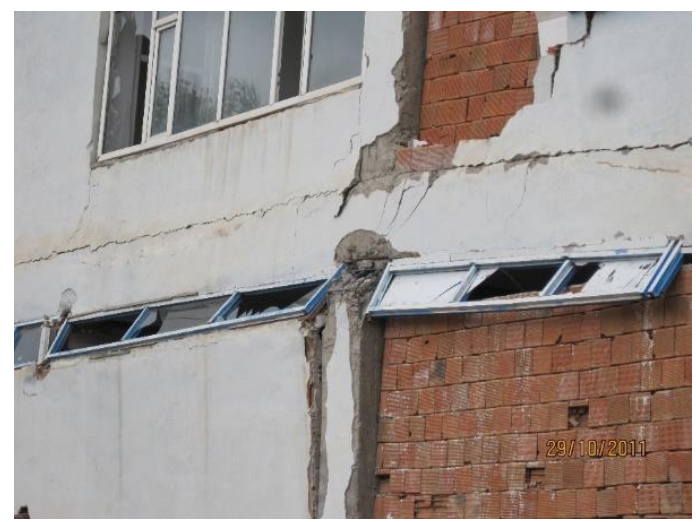

Figure 11 Short column failure

Production of concrete material was not suitable for technique. Concrete was mostly produced on site by machine or by hand mixed by workers. It was not possible to comply with the concrete mix calculation. The cement dosage and water/cement ratio were performed by the workers' own initiative. Therefore, concrete strengths fall down to 7 MPA. Rounded coarse aggregates were used in concrete. There is no bond between cement paste and aggregate. As a result of low concrete strength, reinforcement adherence does not occur (Figure 12).

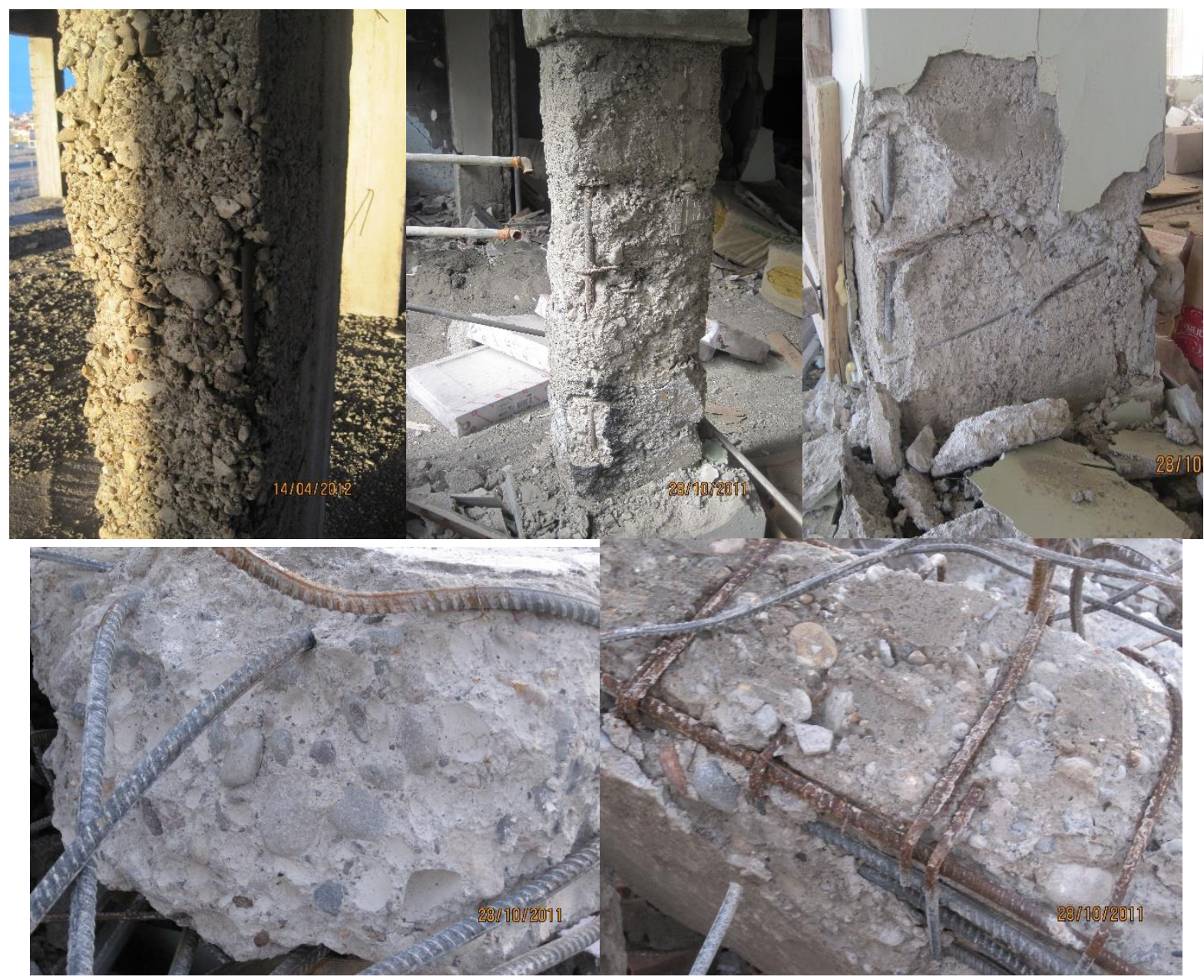

Figure 12 Concrete material condition in RC buildings 
Buildings with the strength and detailing features outlined above collapsed completely even in earthquakes smaller than the design earthquake (Figure 13). The buildings were demolished with the "pancake" shaped floors overlapping. Since the brick walls were damaged heavily in buildings that had not been demolished after the earthquake, the need for temporary housing was very high (Figure 4).

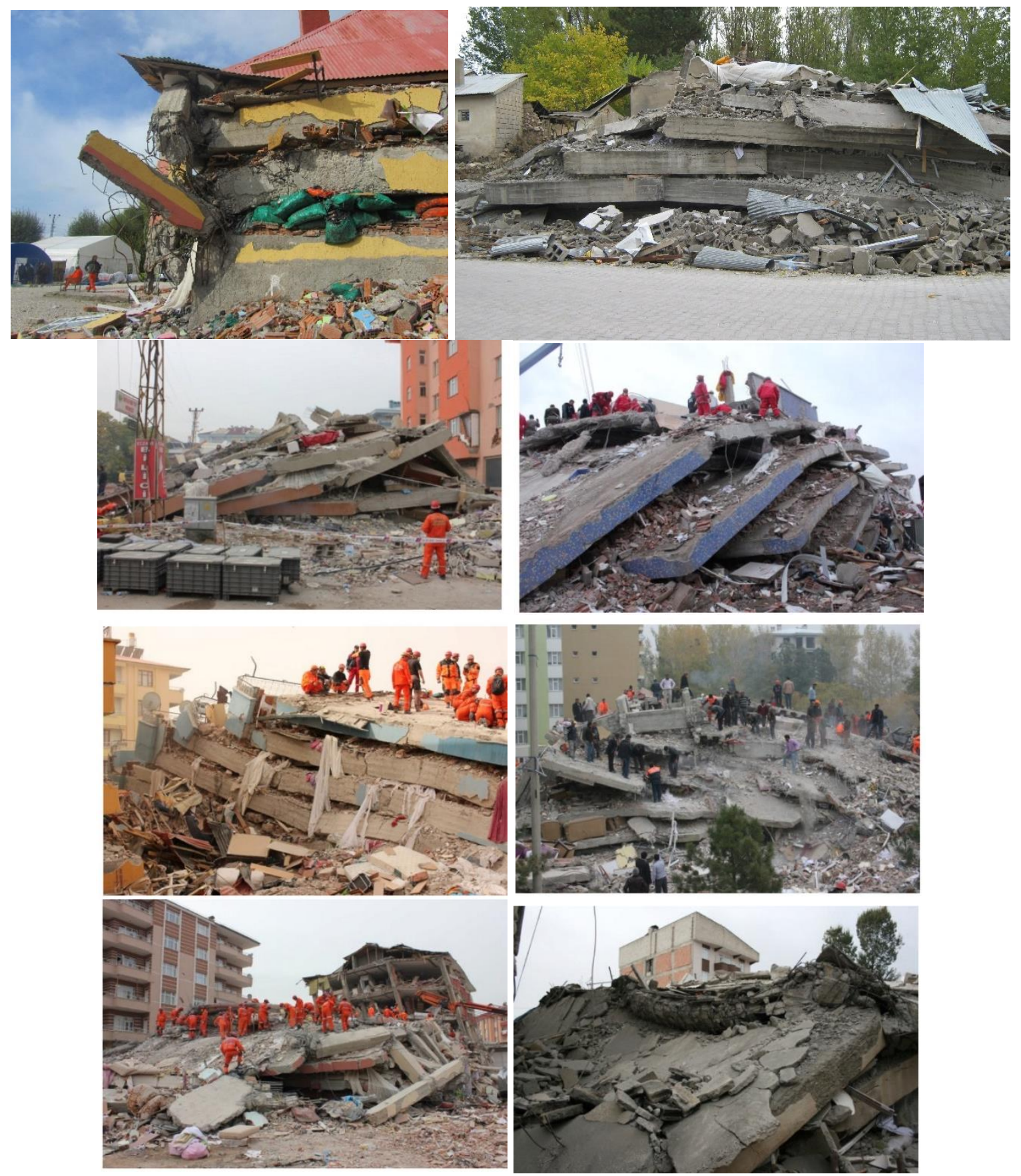

Figure 13 Pancake Collapse of RC structures [11]

\section{Results}

Housing production sector in Turkey is seen as an economic tool and unearned income. Housing production was made by people without professional knowledge. In this production system, engineers were used only for the preparation of the required project and sufficient project costs were not paid. Projects far from earthquake resistant design criteria were created. Engineers were also disabled during the production process on the construction site. There are many unreasonably designed irrational structures with very low material strength and flawed reinforcement details. These structures are only a means of earning money for contractors. 
Users could not perceive the concept of earthquake resistant building. The public could not understand the possibility of an earthquake and the possibility of the building collapse.

An effective building control system has not been established for years. The housing construction process is still the tool of income. While the city plans were being created, a huge income occured and urbanization decisions were shaped by only monetary interest, ignoring possible disasters.

While the users who want to buy a house were only interested in the size of the house and the quality of the material used, they did not question the concrete strength of the columns-beams. The civil engineer was only the person who signed the reinforced concrete project in the process. Engineers signed at costs well below the project cost.

More than 20,000 people died in the 1999 Marmara earthquake. In the next few years, while the earthquake was on the country's agenda, the event was forgotten and the irrational housing production mechanism, which repeats the old mistakes, continued to work.

Currently, there are many buildings that are not resistant to earthquakes. There are not enough initiatives and regulations to detect these buildings. These houses will be out of use only with the occurrence of new earthquakes and destruction.

\section{References}

[1] Murat Bikçe, Tahir Burak Çelik, Failure analysis of newly constructed RC buildings designed according to 2007 Turkish Seismic Code during the October 23, 2011 Van earthquake, Engineering Failure Analysis, Volume 64, June 2016, Pages 67-84

[2] Stephen Platt, Bahar Durmaz Drinkwater, Post-earthquake decision making in Turkey: Studies of Van and İzmir, International Journal of Disaster Risk Reduction, Volume 17, August 2016, Pages 220-237

[3] Erdem Damc1, Rasim Temur, Baris Sayin, Damages and causes on the structures during the October 23, 2011 Van earthquake in Turkey, Case Studies in Construction Materials, Volume 3, December 2015, Pages 112-131

[4] Erkut Sayın, Burak Yön, Yusuf Calayır, Muhammet Karaton, Failures of masonry and adobe buildings during the June 23, 2011 Maden-(Elazığ) earthquake in Turkey, Engineering Failure Analysis, Volume 34, December 2013, Pages 779-791

[5] M. H. Arslan, H. H. Korkmaz, What is to be learned from damage and failure of reinforced concrete structures during recent earthquakes in Turkey?, Engineering Failure Analysis, Volume 14, Issue 1, January 2007, Pages 1-22

[6] Diaa E. Fawzy, Güvenç Arslan, Development of Building Damage Functions for Big Earthquakes in Turkey, Procedia - Social and Behavioral Sciences, Volume 195, 3 July 2015, Pages 2290-2297

[7] Mehmet Inel, Hayri Baytan Ozmen, Huseyin Bilgin, Re-evaluation of building damage during recent earthquakes in Turkey,. Engineering Structures, Volume 30, Issue 2, February 2008, Pages 412-427.

[8] Webpage1: (https://www.aa.com.tr/tr/turkiye/turkiyenin-unutulmayan-16-yillik-acisi-zumrutapartmani-faciasi/1721044)

[9] Webpage2: https://www.insaport.com/haberler/depremden-korunabilmek-icin-kacinilmasi-gereken10-insaat-kusuru/

[10] Webpage3: https://insapedia.com/turkiye-bina-deprem-yonetmeligi-b1-komsu-katlar-arasi-dayanimduzensizligi-zayif-kat/

[11] Gebrail Bekdaş; Baris Sayin; Özlem Çelik Sola; and Abdurrahman Güner, Assessment of the Material Quality of Damaged Structures after Earthquake in Van, Turkey, Journal of Materials in Civil Engineering, Volume 28 Issue 10 - October 2016. 